\title{
TRANSFER OF TECHNOLOGY TO DEVELOPING COUNTRIES: UNILATERAL AND MULTILATERAL POLICY OPTIONS*
}

\author{
Bernard M. Hoekman \\ 1818 H Street, N.W., Washington, DC 20433, World Bank \\ Phone : (202) 473-1185, fax: (202) 522 1159, bhoekman@worldbank.org; \\ Keith E. Maskus \\ UCB 256, University of Colorado, Boulder CO 80309-0256; phone 303-42-7588; fax \\ 303-492-8960; maskus@colorado.edu \\ Kamal Saggi \\ Southern Methodist University, Dallas, TX 75275-0496. Phone (214) 768-3274, fax \\ (214)768-1821; ksaggi@mail.smu.edu
}

\begin{abstract}
This paper analyzes national and international policy options to encourage the international transfer of technology, distinguishing between four major channels of such transfer: trade in products, trade in knowledge, direct foreign investment and intranational and international movement of people. A typology of country types and appropriate policy rules of thumb is developed as a guide to both national policymakers and rule making in the World Trade Organization (WTO). We argue that policies should differentiate between countries. The policy recommendations made illustrate the more general need for such differentiation in the application of special and differential treatment of developing countries in the WTO.
\end{abstract}

\section{JEL classification: F13}

Keywords: Technology transfer, multilateral trade negotiations, economic development, special and differential treatment, WTO

\begin{abstract}
World Bank Policy Research Working Paper 3332, June 2004
The Policy Research Working Paper Series disseminates the findings of work in progress to encourage the exchange of ideas about development issues. An objective of the series is to get the findings out quickly, even if the presentations are less than fully polished. The papers carry the names of the authors and should be cited accordingly. The findings, interpretations, and conclusions expressed in this paper are entirely those of the authors. They do not necessarily represent the view of the World Bank, its Executive Directors, or the countries they represent. Policy Research Working Papers are available online at http://econ. worldbank.org.
\end{abstract}

* This paper draws in part on analysis in Saggi (2003) and Maskus (2003). We are grateful to a referee and Maurice Schiff for helpful comments and to Francis $\mathrm{Ng}$ for assistance with data. 


\section{Introduction}

The importance of international technology transfer (ITT) for economic development can hardly be overstated. Both the acquisition of technology and its diffusion foster productivity growth. As invention and creation processes remain overwhelmingly the province of the OECD countries, most developing countries must rely largely on imported technologies as sources of new productive knowledge. However, considerable amounts of follow-on innovation and adaptation occur in such countries. Indeed, these processes effectively drive technological change in developing nations. ${ }^{1}$

Developing countries have long sought to use both national policies and international agreements to stimulate ITT. National policies range from economy-wide programs (e.g., education) to funding for the creation and acquisition of technology, tax incentives for purchase of capital equipment and intellectual property rights (IPRs). A prominent episode of international efforts to encourage ITT came in the late 1970s, when many developing countries sought a Code of Conduct to regulate technology transfer under United Nations (UN) auspices. ${ }^{2}$ It is difficult to regulate ITT effectively given the incentives for owners not to transfer technology without an adequate return and the problem of monitoring compliance with any rules that might be imposed. This helps explain why ITT is predominately mediated by national policies rather than by international disciplines. While some policies are subject to multilateral disciplines (e.g., subsidies, trade and IPR policies), the rules in place are primarily constraining in nature - they define limits on what is allowed. Multilateral efforts to identify actions that governments should pursue to encourage ITT are largely of a best-endeavor nature.

Starting in the mid 1990s, multilateral disciplines on ITT-related policies began to deepen. The WTO Agreement on Trade-Related Aspects of Intellectual Property Rights (TRIPS) calls on countries to enforce comprehensive minimum standards of IPR protection on a nondiscriminatory basis. It also has provisions relating to ITT. Article 7 notes that IPRs should contribute to the promotion of technological innovation and the transfer and dissemination of technology. Article 8.2 recognizes that countries may wish

\footnotetext{
${ }^{1}$ Evenson and Westphal (1995).

${ }^{2}$ Sell (1998) describes the politics involved and Patel, Roffe and Yusuf (2000) analyze the nature of the negotiations and their aftermath.
} 
to adopt policies to prevent the abuse of IPRs by rights holders or the use of practices that "adversely affect the international transfer of technology." Finally, Article 66.2 calls on developed country WTO members to provide incentives to their enterprises and institutions to promote technology transfer to least-developed countries (LDCs). ${ }^{3}$

In 2001, WTO members established a Working Group on Trade and Technology Transfer to examine the relationship between trade and the transfer of technology and explore what might be done under WTO auspices to increase ITT to developing countries. This can be seen as another reflection of a long history of efforts by developing countries to enhance the relevance of the WTO for development. This paper discusses options that could be pursued in the WTO to promote ITT. Three dimensions are highlighted: safeguarding national "policy space" to address market failures; identifying actions by source countries to encourage ITT; and multilateral initiatives to address international externalities associated with technology markets and/or national policies.

We review the evidence on the major channels of technology transfer in Section 1. Section 2 analyzes the major policy instruments that have been (or could be) used to affect the scope of these channels, in the process enhancing or reducing the amount and/or quality of ITT. Section 3 turns to policy implications, distinguishing between policies of host (importing) and source (exporting) countries, and multilateral cooperation in the WTO. Section 4 concludes. ${ }^{4}$ We should note that the focus of discussion and the literature that is reviewed deal primarily with the industrial and service sectors-we do not review the evidence on technology transfer in agriculture or discuss the policy issues that arise in this sector. ${ }^{5}$

\footnotetext{
${ }^{3}$ LDCs constitute a UN-defined group of currently 49 countries. Membership is a function of a variety of poverty-related criteria.

${ }^{4}$ Some of the issues addressed in this paper have been the subject of discussion in the Working Group on Trade and Technology Transfer. Saggi (2003) provides an in-depth analysis of the discussions during 2002.

${ }^{5}$ As noted by a referee, in agriculture there has been a marked shift from public sector R\&D and new seeds and farming technologies being freely disseminated through international agricultural research centers and agricultural extension systems, to an environment where most agricultural $R \& D$ is conducted by the private sector and new technologies are proprietary. How technology transfer takes place in this new environment, the role of the traditional network of international agricultural research centers, and the incentive effects
} 


\section{Channels of Technology Transfer}

Numerous channels exist through which ITT may occur. Trade in goods and services is one. All exports bear some potential for transmitting technological information. Imported capital goods and technological inputs can directly improve productivity by being used in production processes. A second channel is foreign direct investment (FDI). Multinational enterprises (MNEs) generally transfer technological information to their subsidiaries, some of which may 'leak' into the host economy. A third major channel of ITT is direct trade in knowledge via technology licensing. This may occur within firms, among joint ventures, or between unrelated firms. Licensing and FDI are often substitutes. Which form is preferable to technology owners depends on many factors, including the strength of IPR protection. Patents, trade secrets, copyrights, and trademarks can all serve as direct facilitators of knowledge transfers.

Market transactions in technology are hampered by three major problems: $(i)$ asymmetric information; (ii) market power; and (iii) externalities.

Asymmetric Information Technology transfer involves exchange of information between those that have it and those that do not. The former cannot fully reveal their knowledge without destroying the basis for trade, creating a well known problem of asymmetric information-buyers cannot fully determine the value of the information before buying it. This can lead to large transactions costs that stifle market-based technology transfer. In the international context, information problems are more severe and the enforcement of contracts more difficult to achieve. The received theory of the multinational firm holds that such firms establish foreign subsidiaries because of the difficulty of using markets to profit from their proprietary technologies.

Market Power Owners of new technologies typically have substantial market power resulting from lead time and patents and other IPRs. This necessarily implies that the price of technology will exceed the socially optimal level (i.e., marginal cost). While this divergence between price and cost allows innovators to profit from their innovation, it implies a reduction in (static) national welfare of those importing technologies.

created by the high trade barriers in agriculture, are important questions that this paper does not address. See Gisselquist, Nash and Pray (2002) and Evenson (2004). 
Externalities These may arise if the costs and benefits of technology exchange are not fully internalized by those involved. A major share of benefits to recipient countries of ITT is likely to arise from uncompensated spillovers. Positive spillovers exist whenever technological information is diffused into the wider economy and the technology provider cannot extract the economic value of that diffusion. Spillovers can arise from imitation, trade, licensing, FDI and movement of people.

These market failures imply a potential for policies to increase welfare by encouraging ITT. To be effective, policy must alter the incentives of private agents that possess innovative technologies in the "right" way. In practice, the potential for welfareimproving policy may not be realized due to mistakes or rent-seeking activity.

\section{Patterns of ITT}

A major problem for policy (and analysis) is that ITT flows are not easily measured. Much ITT is implicit in international trade in goods, services and factors, and it is difficult, if not impossible, to break out the proportion of prices or flows reflecting technology content. Almost by definition, imitation goes unreported and spillovers cannot be directly measured. Thus, it is difficult for policymakers to identify the optimal policy, or even to rank-order policies according to effectiveness.

Data on the value of some of the relevant flows are reported in Table 1. All are imperfect measures of the importance of the alternative channels of ITT, but do provide an informative picture of trends and shares. Regardless of the channel, low-income countries account for only a small share of total outward flows from OECD countries. Moreover, this share has been falling over time. 
Table 1: Exports of Capital-Intensive, Skilled Labor-Intensive and TechnologyIntensive Goods, Royalty Income Earned and Net FDI Outflows from High-Income OECD Countries, 1970 and 2001, US\$ billion and percent

\begin{tabular}{lcccccccccc}
\hline & $\begin{array}{c}\text { Trade, Capital- } \\
\text { intensive }\end{array}$ & \multicolumn{2}{c}{$\begin{array}{c}\text { Trade, Skilled } \\
\text { Labor intensive }\end{array}$} & $\begin{array}{c}\text { Trade, } \\
\text { High-technology }\end{array}$ & Royalties & Net FDI flows \\
\hline Value (\$bn): & $\mathbf{1 9 7 0}$ & $\mathbf{2 0 0 1}$ & $\mathbf{1 9 7 0}$ & $\mathbf{2 0 0 1}$ & $\mathbf{1 9 7 0}$ & $\mathbf{2 0 0 1}$ & $\mathbf{1 9 7 0}$ & $\mathbf{2 0 0 1}$ & $\mathbf{1 9 7 0}$ & $\mathbf{2 0 0 1}$ \\
\cline { 2 - 10 } High income & 45.8 & $1,108.0$ & 43.7 & 736.7 & 25.8 & 739.3 & 2.8 & 71.2 & 6.9 & 472.1 \\
Low income & 2.8 & 32.8 & 2.4 & 13.1 & 1.2 & 16.1 & 0.0 & 0.02 & 0.3 & 8.1 \\
Lower middle income & 8.4 & 183.4 & 5.7 & 60.0 & 3.5 & 104.3 & 0.0 & 0.7 & 0.9 & 105.6 \\
Upper middle income & 7.7 & 318.0 & 5.2 & 126.9 & 3.8 & 200.0 & 0.0 & 1.8 & 0.6 & 69.4 \\
Sub-Saharan states & 1.5 & 10.6 & 1.5 & 6.0 & 0.7 & 5.6 & 0.0 & 0.02 & 0.1 & 5.5 \\
Shares (\%): & & & & & & & & & & 79.9 \\
High income & 70.8 & 67.5 & 76.6 & 78.7 & 75.4 & 69.8 & 99.7 & 96.7 & 79.9 & 72.0 \\
Low income & 4.4 & 2.0 & 4.2 & 1.4 & 3.5 & 1.5 & 0.0 & 0.0 & 3.2 & 1.2 \\
Lower middle income & 12.9 & 11.2 & 10.0 & 6.4 & 10.1 & 9.8 & 0.0 & 0.9 & 9.9 & 16.1 \\
Upper middle income & 11.9 & 19.4 & 9.1 & 13.5 & 11.0 & 18.9 & 0.0 & 2.4 & 7.1 & 10.6 \\
Sub-Saharan states & 2.3 & 0.6 & 2.8 & 0.6 & 2.0 & 0.5 & 0.0 & 0.0 & 1.2 & 0.8 \\
\hline
\end{tabular}

Notes: Country groups are as defined by World Bank; High income-OECD countries minus Mexico,

Korea and Turkey; Sub-Sahara excludes South Africa. Capital and skilled labor-intensive goods distinction based on factor intensity using the SITC classification. High-technology defined using R\&D intensity. Source: UN COMTRADE database (trade); IMF Balance of Payments statistics (royalties) and UNCTAD, World Investment Report (FDI).

Table 2: Imports of Capital-Intensive, Skilled Labor-Intensive and Technology-Intensive Goods, and Royalty Income Paid by High-Income OECD Countries, 1970 and 2001, US\$ billion and percent

\begin{tabular}{|c|c|c|c|c|c|c|c|c|}
\hline \multirow[b]{2}{*}{ Value (\$bn): } & \multicolumn{2}{|c|}{$\begin{array}{l}\text { Trade, Capital- } \\
\text { intensive }\end{array}$} & \multicolumn{2}{|c|}{$\begin{array}{l}\text { Trade, Skilled } \\
\text { Labor intensive }\end{array}$} & \multicolumn{2}{|c|}{$\begin{array}{c}\text { Trade, } \\
\text { High-technology }\end{array}$} & \multicolumn{2}{|c|}{ Royalties } \\
\hline & 1970 & 2001 & 1970 & 2001 & 1970 & 2001 & 1970 & 2001 \\
\hline High income OECD & 49.1 & $1,108.8$ & 43.8 & 743.0 & 26.9 & 730.5 & 0.8 & 63.7 \\
\hline Low-income & 0.1 & 9.6 & 0.1 & 8.9 & 0.1 & 8.1 & 0 & 0.1 \\
\hline Lower middle income & 0.5 & 127.3 & 0.3 & 68.7 & 0.3 & 104.4 & 0.1 & 6.0 \\
\hline Upper middle income & 1.0 & 263.8 & 0.8 & 133.2 & 0.9 & 220.7 & 0 & 6.7 \\
\hline Sub-Saharan states & 0.06 & 0.5 & 0.01 & 0.3 & 0.06 & 0.3 & 0 & 0.1 \\
\hline \multicolumn{9}{|l|}{ Shares (\%): } \\
\hline High income OECD & 96.0 & 73.4 & 97.2 & 77.9 & 95.2 & 68.7 & 93.0 & 83.2 \\
\hline Low income & 0.2 & 0.6 & 0.2 & 0.9 & 0.3 & 0.8 & 0.0 & 0.1 \\
\hline Lower middle income & 1.0 & 8.4 & 0.8 & 7.2 & 1.2 & 9.8 & 6.6 & 7.8 \\
\hline Upper middle income & 2.0 & 17.5 & 1.9 & 14.0 & 3.1 & 20.7 & 0.4 & 8.7 \\
\hline Sub-Saharan states & 0.1 & 0.03 & 0.04 & 0.03 & 0.20 & 0.03 & 0.00 & 0.16 \\
\hline
\end{tabular}

Note: See Table 1 for definitions and sources. 
Total trade in technology-intensive goods grew rapidly in the last three decades, with capital-intensive exports expanding most rapidly. Upper-middle-income nations constitute the fastest-growing market for technology-intensive exports from OECD countries. Licensing and other types of arm's-length trade in technology - measured by royalty income flows - are largely the domain of OECD countries. The flows involved are not negligible - over $\$ 70$ billion in 2001. Upper-middle-income countries have become players in this market, although they account for less than 3 percent of total OECD exports. Among the various channels for ITT, lower-middle-income countries have the greatest share in outward OECD FDI flows. For these countries, FDI shares grew faster than technology trade or trade in technology-intensive goods. The same qualitative conclusion holds for low-income countries-FDI grew the most between 1970 and 2001, although the share of low-income countries in total trade and FDI declined.

A qualitatively similar conclusion holds for imports by high-income OECD countries (Table 2). Upper-middle-income countries have also become suppliers of technology-intensive products. The shifts here are even more dramatic and reflect the emergence of East Asian countries as producers of electronic equipment. Lower-middleincome countries have also become sources of such products. Their share of the OECD market expanded more than their share of the OECD export market. Both categories of middle-income economies have become generators of technology, as reflected in royalty income of some $\$ 12.7$ billion in 2001 . Low-income countries are simply not players. ${ }^{6}$

As discussed further below, the relationships between the various channels of ITT are complex - trade and FDI are often complements, whereas FDI and licensing may be either complements or substitutes. Movement of people is often needed to allow trade, licensing or FDI to occur or to increase the efficiency of such transactions. A very imperfect measure of the total interaction between suppliers of technology and developing countries that captures both movement of people and trade/FDI flows is voice telecommunications traffic (Table 3 ). The developing country share of outward traffic from high-income countries is much more symmetrically distributed than is the case for 
Table 3: Voice Telecommunications Traffic, US, UK and Japan, 1999

\begin{tabular}{llccccc}
\hline \multicolumn{2}{l}{ Minutes (million) } & $\begin{array}{c}\text { High- } \\
\text { income }\end{array}$ & $\begin{array}{c}\text { Low } \\
\text { income }\end{array}$ & $\begin{array}{c}\text { Lower middle } \\
\text { income }\end{array}$ & $\begin{array}{c}\text { Upper middle } \\
\text { income }\end{array}$ & $\begin{array}{c}\text { Sub-Saharan } \\
\text { Africa }\end{array}$ \\
\hline US & Outward & 12,669 & 2,447 & 5,740 & 7,720 & 458 \\
\multirow{4}{*}{ UK } & Inward & 7,270 & 154 & 821 & 2,310 & 45 \\
& Outward & 7,211 & 690 & 1,068 & 964 & 288 \\
\multirow{5}{*}{ Japan } & Inward & 5,586 & 190 & 414 & 581 & 100 \\
\multirow{3}{*}{ Shares (\%) } & Outward & 1,221 & 87 & 694 & 474 & 38 \\
US & Inward & 630 & 41 & 237 & 352 & 0 \\
\multirow{4}{*}{ UK } & Outward & 44.3 & 8.6 & 20.1 & 27.0 & 1.6 \\
& Inward & 68.9 & 1.5 & 7.8 & 21.9 & 0.4 \\
\multirow{2}{*}{ Japan } & Outward & 72.6 & 7.0 & 10.8 & 9.7 & 2.9 \\
& Inward & 82.5 & 2.8 & 6.1 & 8.6 & 1.5 \\
\hline
\end{tabular}

Source: ITU.

trade or FDI — in part reflecting (temporary) employment of foreign nationals — while incoming calls are more biased towards OECD countries. ${ }^{7}$

\section{Trade in goods}

We turn next to a brief discussion of the nature of these various channels. Endogenous growth models assign a central role to technological change (Grossman and Helpman 1991), based on the idea that entrepreneurs conduct R\&D to profit from monopoly power that results from innovation. Growth may be sustained through the creation of new products that expands the knowledge stock and lowers the cost of innovation.

Alternatively, consumers may be willing to pay a premium for higher quality (innovative) products. As new products result from new ideas, international trade can help transmit embodied knowledge internationally.

Barriers to technology adoption are a key determinant of international differences in per capita income (Parente and Prescott 1994). Increased trade openness can increase growth by lowering these barriers. Trade can contribute to ITT by allowing reverse

\footnotetext{
${ }^{6}$ Data on movement of people and the associated ITT are not collected and reported systematically.
} 
engineering by local firms and by granting firms access to new machinery and equipment. Coe and Helpman $(1995,1997)$ find that foreign R\&D embodied in traded goods has a significantly positive impact on total factor productivity (TFP) of importing countries. This impact is greater the more open the countries are, the more skilled is their labor force, and in the case of developing countries, the more trade is with developed countries (Schiff, Yang and Olarreaga 2002). Investment in R\&D has a greater impact on TFP than does openness to trade among OECD members, but openness has a greater impact on TFP than R\&D embodied in North-South trade (Schiff and Wang 2002). For North-South trade, Schiff and Wang also find that in low R\&D-intensity industries, openness (R\&D) has a positive (no) impact on TFP, while R\&D has a positive effect on TFP in R\&D-intensive industries, although this effect is still smaller than that of openness. Variations in capital goods trade can better explain cross-country differences in productivity than can overall trade (e.g., Eaton and Kortum 1999).

These results suggest that open trade policies are critical for developing countries in attracting technology. But openness is not sufficient-there needs to be absorptive capacity and ability to adapt foreign technology, both of which are related to human capital endowments and investment in $\mathrm{R} \& \mathrm{D}$ intensive industries. In developing countries, technology acquisition often amounts to adapting existing methods to local circumstances (Evenson and Westphal 1995). Gradual adoption of new techniques or new inputs is optimal for risk-averse producers in the face of costly adoption and uncertain returns. Producers need to learn how to apply the new technology and will often start by applying it to a small part of their output and, if profitable, increase its application gradually over time (Tybout 2000).

The further the 'technological distance' of a country from the global frontier, the more difficult it is to absorb information effectively into production systems (Keller 2002). Countries tend to acquire international technology more readily if domestic firms have local R\&D programs, there are domestic private and public research laboratories and universities, and there exists a sound basis of technical skills and human capital. All this reduces the costs of imitation, adaptation, and follow-on innovation.

\footnotetext{
${ }^{7}$ In part this will be due to telecom access and cost factors in developing countries. Note that the data in Table 3 may be affected by pricing incentives, including incentives to use call back systems in the late
} 


\section{Foreign Direct Investment}

FDI may provide developing countries with more efficient foreign technologies and result in technological spillovers and greater competition. In addition to demonstration effects (imitation), spillovers may arise because of labor turnover and vertical linkages (MNEs transfer technology to local firms that are suppliers of intermediates or buyers of their output). Case studies suggest that substantial technology diffusion occurs due to FDI (Blomstrom and Kokko 1997). Econometric studies are more diverse, some finding that firms in sectors with a relatively high MNE presence tend to be more productive (Kokko et al 1997), while others find that domestically-held firms may actually do worse as the foreign presence in their industry increases (e.g., Aitken and Harrison 1994). Negative spillover effects may occur in the short run if MNEs siphon off domestic demand or bid away high-quality labor. Vertical technology transfer from MNEs to local suppliers has been documented to occur through firms from industrialized countries buying the output of Asian firms to sell under their own brand names. Such relations may result in transfers of technical information from foreign buyers. ${ }^{8}$

\section{Licensing}

Licensing is an important source of ITT for developing countries Correa (2003). It typically involves the purchase of production or distribution rights and the underlying technical information and know-how. ${ }^{9}$ The general determinants of decisions on where to license are similar to those involving FDI. Thus, market size, anticipated growth, proximity, the stock of human capital, the ability to repatriate licensing rents, and the investment climate all affect licensing flows. Another factor is the confidence of licensor firms that proprietary technologies will not leak into the host economy. To the extent that transferred technologies are easily copied, industrial espionage is common, or technical personnel can 'defect' to competitor firms, foreign firms may prefer FDI. Where this is

1990s, especially in the US. The sum of incoming and outgoing traffic will be less sensitive to such factors.

${ }^{8}$ Mexico's maquiladora sector is a recent example of vertical ITT. Most maquiladoras began as subsidiaries of US firms that shifted labor-intensive assembly operations to Mexico. However, over time the maquiladoras adopted more sophisticated production techniques, many of which were imported from the US (Saggi 2002). Similar findings apply to transition economies, see e.g., Smarzynska (2003).

${ }^{9}$ In the case of intra-firm ITT the MNE retains proprietary control of the know-how, while in the arm'slength case access to these assets must be provided the licensee. 
not possible, firms may choose not to engage in licensing at all or transfer lagging technologies (Maskus 2000, Saggi 1996). Successful transfer typically requires capacity to learn and investments to apply technologies in production processes. This explains why countries with substantial engineering skills and R\&D programs for adaptation and learning are greater recipients of licensing flows than others (Yang and Maskus 2001).

\section{Movement of People}

Little attention has been given to the role of labor turnover as a channel for ITT. Some studies have found that intra-national labor turnover from MNEs to local firms is limited (e.g., Gershenberg 1987), while others find the opposite (Rhee 1990). An explanation is that in countries where local firms are not too far behind MNEs in technical terms, labor turnover is more likely. Thus, the ability of local firms to absorb new technologies is a determinant of whether labor turnover is a means of technology diffusion. The feasibility (profitability) of creating new companies is another factor (Saggi 2002).

International movement of people - associated with nationals studying or working abroad for a limited period and applying their new knowledge when they return, or the inward movement of foreign nationals into the country - is another potential channel for ITT. A challenge for developing countries is to facilitate temporary movement abroad and to encourage returnees to undertake local research and business development.

\section{Technology-related Policies and ITT}

While many countries have historically engaged in infant industry protection, the evidence suggests that diffusion of knowledge is facilitated by an open trade regime (Saggi 2002). Firms should have undistorted access to capital equipment and imported inputs that embody foreign knowledge. But the case for open markets extends to other products as well, as the associated increase in competition will reduce price-cost markups. At the same time, given that technology markets are associated with increasing returns, imperfect competition and externalities, there is not an unconditional argument against trade protection. The conclusions hinge importantly on the scope of knowledge spillovers. International knowledge spillovers strongly tilt the balance in favor of free 
trade, whereas national spillovers create a potential role for trade-policy intervention. ${ }^{10}$ For example, if productivity improvements depend only on a country's own R\&D, a case can be made for policies that ensure that industries in which such improvements occur at a rapid rate are not all located elsewhere.

The available evidence suggests that spillovers are mostly international (Eaton and Kortum 1996). Even if spillovers were intra-national, trade policies would be neither efficient nor an effective instrument. Instead, general policies that increase the incentives of agents to undertake activities that generate social benefits exceeding private returns, without simultaneously creating additional distortions, would be more appropriate. Trade policy does little to encourage local R\&D and necessarily leads to other distortions.

One set of trade policies that is often motivated on the basis of ITT are traderelated investment measures (TRIMs). Examples are local content and technology transfer requirements for foreign investors. TRIMs involve discrimination against imports by creating incentives (in addition to import tariffs) to source inputs from domestic producers. In the ITT context, a motivation for TRIMs is that foreign firms might be expected to transfer knowledge to ensure that the local inputs purchased satisfy its specifications. TRIMs act as an implicit tariff on intermediate goods imports because manufacturers are forced to use higher-cost local inputs. They are inferior to tariffs in welfare terms as no tariff revenue is generated. Moreover, they provide little or no incentive for the protected producers of intermediate goods to acquire more knowledge.

\section{Licensing and FDI-related policies}

Historically, restrictive trade policies were often complemented by restrictions on FDI (in part to prevent tariff-jumping investment). Thus, Japan, Korea, and Taiwan (China) all imposed restrictions on FDI at various points in time. However, policies were often more welcoming toward other modes of ITT, including trade policies affecting machinery and equipment, and licensing of foreign technology. More recently, national FDI policies have generally become more liberal but policy might differentiate between joint ventures and fully owned subsidiaries of multinationals. For example, China, among others, has been more encouraging of joint ventures than inward FDI. Such a policy stance may be

\footnotetext{
${ }^{10}$ Indeed, in the presence of positive externalities from trade, there is a potential case for import subsidies. However, in practice governments will not have the information needed to identify which goods give rise to
} 
an attempt to protect incumbent firms from competing with MNEs, or may reflect a desire to maximize technology transfer to local agents. Studies indicate that technologies transferred to wholly owned subsidiaries are of a newer vintage than licensed technologies or those transferred to joint ventures (e.g., Mansfield and Romeo 1980). Thus, by forcing MNEs to license their technologies host countries might be lowering the quality of technologies they receive as well as reducing the incentives to invest at all.

While the magnitude of ITT undertaken by MNEs need not be socially optimal, considerable evidence exists that such firms are keen to transfer technology to their local suppliers. ${ }^{11}$ Policies that facilitate this process, as opposed to those insisting that MNEs engage in ITT to local competitors, have a greater likelihood of being successful. In practice, of course, many countries actively seek to attract foreign investors through upfront subsidies, tax holidays, and other grants. For there to be a rationale for such investment incentives host countries must enjoy positive externalities from inward FDI. The prevalence of "follow the leader" behavior among MNEs provides another potential case for FDI incentives. Given the oligopolistic nature of markets within which FDI occurs, a new entrant may attract investments by both competitors and upstream suppliers. If so, competition at multiple stages of production may increase, thereby improving efficiency as well as overall output and employment. An implication is that a host country may be able to unleash a sequence of investments by successfully inducing FDI from one or two major firms.

More broadly, if the local economy lacks a well-developed network of potential suppliers, MNEs might be hesitant to invest and local suppliers may not develop because of lack of demand. In the presence of such interdependence, growth may be constrained by a coordination problem that can partially be resolved by initiating investments from key firms. Of course, such coordination problems cannot be tackled solely through investment incentives. Policy efforts need to focus on improving the investment climate and reducing the costs of absorbing technology. The latter task is complex and involves building human capital and expanding national innovation systems. Thus, while there

${ }^{11}$ Moran (1998) discusses several case studies that document this process. 
may be a case for incentives, it is a conditional one. To be effective, the preconditions relating to the investment climate and absorptive capacity must be satisfied. ${ }^{12}$

\section{General vs. specific domestic technology-related subsidy policies}

A substantial share of R\&D benefits may be local in nature, leading to a concentration of innovative activity, often around academic research centers (Audretsch and Feldman 1994). This may provide a case for specific R\&D-related subsidies as well as support of basic research and training to expand absorptive capacity in a country. ${ }^{13}$ Many studies indicate that absorptive capacity in the host country is crucial for obtaining significant spillover benefits from trade or FDI. Without adequate human capital or investments in R\&D, spillovers may simply be infeasible. The implication is that liberalization of trade and open FDI policies need to be complemented by policies with respect to education, $\mathrm{R} \& \mathrm{D}$, and human capital accumulation for countries to take full advantage of ITT.

Of greatest relevance to the subject of ITT is the role that subsidies can play to facilitate learning, technology acquisition, and dynamic comparative advantage where returns to such activities cannot be appropriated by private agents and hence will not be undertaken by any individual firm. Commentators such as Amsden (1989) argue that policy interventions, including implicit or explicit subsidies, lay behind the economic "miracles" in Korea and Taiwan (China). Their case is that carefully targeted subsidies allowed these governments to stimulate key sectors that became efficient in their own right and provided positive spillovers.

It is important to differentiate between sector-specific subsidies and general policies facilitating learning and the development of enterprise. In a recent comprehensive retrospective on the East Asian development experience, Noland and Pack (2003) argue that sector-specific policies did not result in high rates of TFP growth for manufacturing. In the case of countries such as Korea and Taiwan, TFP growth was not much higher than in the OECD. In India, selective interventionist policies were

\footnotetext{
${ }^{12}$ Care must also be taken in terms of the sectoral allocation of incentives. In particular, the case for seeking to attract 'hi-tech' investments is weak. Investment in simple activities (such as transportation and other fundamental services) might have larger returns even if they do not result in large technology spillovers. Industrialization can be subject to large coordination failures and investment in local infrastructure can help resolve such failures, in the process improving the investment climate.

${ }^{13}$ As noted below, the first avenue raises concerns regarding the ability of government to identify the right activities and prevent capture of policies.
} 
associated with declining TFP growth rates, while the opening of the economy led to an increase in TFP growth rates (Krishna and Mitra 1998).

The case for general policy supports for certain types of activity, including innovation, education, transport infrastructure and similar public goods is uncontroversial. The same is true for policies aimed to promote socially beneficial activities. Markets do fail and there may be good rationales for governments to provide incentives for firms and agents to undertake activities that would otherwise be undersupplied. An important example that has a direct bearing on the subject at hand is the learning externality analyzed by Hausmann and Rodrik (2002). In that situation the market undersupplies investment by firms in new (nontraditional) activities because of appropriability problems - as soon as an entrepreneur is successful in identifying a profitable new production opportunity, entry by imitators prevents recouping of costs. If so, a subsidy or similar incentive can help expand innovation and risk taking. ${ }^{14}$

The efficient use of support policies requires that governments are effective at both identifying cases that justify intervention and at implementing these appropriately. In practice, governments may fail at doing so and the policy problem is to assess the relative sizes of government and market failure. Among the potential problems are that subsidies can serve to support inefficiency; that firms may behave strategically (by underinvesting, for example) in order to win subsidies; and that subsidies can result in corruption, bad corporate governance and rent-seeking behavior. The biggest challenge of implementing subsidies is that they are difficult to control. Government needs to establish an effective and credible exit strategy that weeds out successful efforts from unsuccessful ones. The capabilities and autonomy of the state play a fundamental role in implementing subsidy policies effectively (Rodrik 1993).

\section{IPRs and Technology Transfer}

IPRs can support markets in technology, including ITT. ${ }^{15}$ Absent IPRs firms would be less willing to engage in technology transactions. Patents and trade secrets provide a legal basis for revealing the proprietary characteristics of technologies to subsidiaries and

\footnotetext{
${ }^{14}$ In many cases IPRs will not be an effective instrument to ensure that successful entrepreneurs obtain a positive rate of return. Moreover, the objective here is to encourage economy-wide imitation of 'revealed success' through entry into new productive activities.

${ }^{15}$ See Arora, Fosfuri, and Gambardella (2001) and Maskus (2000).
} 
licensees, supporting the formation of licensing contracts. ${ }^{16}$ Patent protection both increases flows of ITT to countries with technological capacity and shifts incentives for investors between FDI and licensing. The empirical literature suggests the following:

- Patent applications from foreign nations are strongly associated with productivity growth in recipient countries (Eaton and Kortum 1996). With the exception of the United States, OECD countries obtain more than 50 percent of productivity growth by importing technologies (patents). This proportion is higher for small economies. Thus, trade in ideas is a major factor in world economic growth.

- Patent citations reflect knowledge flows across borders. While there is a limited amount of diffusion overall, owing to distance, borders, and differences across regions in technological specialization (Peri 2003), the most significant patents are widely diffused, as is knowledge in highly technological sectors. There is a strongly positive impact of knowledge flows on international innovation.

- International trade flows, especially in patent-sensitive industries, respond positively to increases in patent rights among middle-income and large developing countries. An important reason is that these countries represent a competitive imitation threat with weak IPRs and stronger patents expand the market for foreign exporters (Smith 2001). However, trade flows to poor countries are not responsive to patent rights.

- The evidence on patents and inward FDI is mixed but recent studies uniformly find positive impacts among middle-income and large developing countries. However, in poor countries, patents do not expand FDI (Smith 2001; Blyde and Acea 2002). ${ }^{17}$

- Strengthening IPRs shifts ITT from exports and FDI toward licensing and positively affects knowledge inflows, measured as R\&D expenditures undertaken on behalf of affiliates. These findings apply only to recipient countries with strong imitative abilities; the impact is zero in other countries (Smith 2001; Nicholson 2002).

- The sophistication of technologies transferred rises with the strength of IPR protection and domestic capacities to absorb and improve technology, as foreign firms become more willing to transact more advanced products and processes.

\footnotetext{
${ }^{16}$ See Correa (2003) for a counter argument that strong IPRs may stifle ITT as firms exploit market power.

${ }^{17}$ See also Smarzynska (2004) for an analysis of the impact of IPRs on FDI in Central Europe.
} 
A common finding of the literature is that the poorest countries are unlikely to benefit from strong IPRs (McCalman 2001). Stronger patent rights may be expected to raise considerably the rents earned by international firms as IPRs become more valuable, obliging developing countries to pay more for the average inward flow of protected technology. These are also countries where ITT-related spillovers are likely to be small at best, given limited absorptive capacity. The implications are that in poor countries policy should aim at lowering costs of imports of IPR-intensive goods and technology, and raising the capacity to absorb and adapt technologies.

\section{National Policies and International Cooperation: Issues and Options}

Asymmetric information problems and externalities (fear of "leakage") can significantly reduce incentives for ITT, while market power created by IPRs will lead to pricing above marginal cost. This suggests policy should aim at: (i) increasing access of local buyers to the international stock of knowledge and increasing the ability of technology owners to signal the true value of their inventions to buyers; (ii) reducing the cost of acquiring and absorbing existing technologies; and (iii) increasing incentives for domestic innovation. In what follows we discuss in turn possible policy options for host countries, source countries, and international cooperation.

\section{Host-Country Policies}

A basic challenge for host developing countries is to improve the local environment for ITT and its diffusion as well as the investment climate in general. Both FDI and licensing respond to factors such as an effective infrastructure, transparency and stability in government, and a reasonably open trade and investment regime. Also important is a domestic entrepreneurial environment that attracts skilled workers who reside in developed countries. Given that backward spillovers from ITT are strongest in countries where MNEs are able to work with competitive suppliers in order to increase their productivity, reducing entry barriers in supplier industries can also assist ITT.

An important determinant of the ability to absorb and adapt technology is the return to investing in at least simple $R \& D$ capacity. To the extent that prevailing technology policies, restrictions on capital markets, and tax policies lower this return or 
discourage such investments, they could be reformed to encourage more innovation. Similarly, absorption of ITT and its translation into greater competition depends on having an adequate supply of engineering and management skills. In this regard, domestic education and training policies are important. Governments can reduce the technological "distance" between local and foreign firms by establishing national or regional innovation systems that encourage local $R \& D$, transfer knowledge from universities and public laboratories to domestic firms, and promote use of telecommunications, e-commerce, biotechnologies, and other cost-saving technologies.

Host-country governments also need to recognize, and perhaps reward, the risktaking involved in adoption of foreign technologies. More specifically, suppose domestic firms are considering the costly adoption of some foreign technology but significant uncertainty exists regarding the degree to which the technology can be adopted effectively in the local environment. Under such a scenario, those firms that adopt the technology first will generate positive spillovers for others who can "watch and learn" from their risky experiments. In the presence of such informational externalities, it may be optimal for a host country to subsidize the adoption of foreign technologies or else no one firm may be willing to bear the cost of technology adoption for fear of not making a positive return on its investment. ${ }^{18}$

At a general level, theory does not provide unambiguous guidance regarding the relative social payoff to using (encouraging) alternative channels of ITT. As mentioned, much depends on whether spillovers are international or intra-national, on the capacities to absorb and adapt technologies, and other factors. A 'one size fits all' approach to policy will clearly be inappropriate. Consider, for example, the choice between licensing and FDI from a host country's viewpoint. If market structure is not competitive (as is likely in markets where ITT occurs), the choice between licensing and FDI is not a simple matter. Concerns about the market power of MNEs frequently miss the point that the alternative to having them compete might be domestic incumbents with significant market power. Such incumbents will generally possess technologies inferior to those of MNEs. If there exists a strong domestic incumbent who can thwart further domestic 
entry, limiting FDI and encouraging licensing of technology to that incumbent can increase its market power vis-à-vis its weaker domestic rivals (Saggi 1996). ${ }^{19}$ On the other hand, suppose FDI were restricted but technology licensing were encouraged and all domestic firms that wished to obtain a license could do so. Licensing might then be preferable to FDI if the technology owner agrees to transfer the technology.

Given the limited guidance offered by theory, it is helpful to briefly revisit the history of successful efforts to move up the technology ladder. Japan is a pre-eminent example of a country that developed technological capacity rapidly. One reason for Japan's rapid growth and industrialization after World War II was that its patent system was designed for both small-scale innovation and diffusion. The system encouraged incremental and adaptive innovation by Japanese firms and promoted the diffusion of knowledge, including foreign technologies, into the wider economy (Maskus 2000). Japan also encouraged foreign firms to license technologies to Japanese firms, in part through restrictions on FDI. This system encouraged the filing of large numbers of utility model applications for incremental innovations that were based partly on laid-open patent applications. Statistically, utility model filings had a positive and significant impact on Japanese TFP growth between 1969-93 (Maskus and McDaniel 1999).

Korea is another technology follower that encouraged learning via duplicative imitation of mature technologies that foreign firms had permitted to enter the public domain or were willing to provide cheaply. ${ }^{20}$ IPRs were weak and encouraged imitation and adaptation. In the 1970s Korea specialized in labor-intensive goods at the end of the product life cycle, with firms importing off the shelf technologies and adapting them to produce slightly differentiated goods. Government essentially promoted the development of technical skills through education and workplace training and ensuring the absence of anti-export bias. In the 1980s, Korea shifted to creative imitation, involving more significant transformation of imported technologies. This required domestic R\&D and inhouse research capabilities to adapt technology. The government also became more welcoming to formal channels of ITT and strengthened the IPR regime.

\footnotetext{
${ }^{18}$ Note that the issue here cannot be solved through a government buying the knowledge and providing it to all interested parties. The knowledge concerned is not known (available) ex ante and cannot be protected ex post through patents or similar instruments.

${ }^{19}$ Of course, an offsetting factor is that rents will be domestic.
} 
Brazil, Mexico, Malaysia, and the export-intensive regions of China and India are other examples of movement from pure to creative imitation. In these cases, IPR protection was initially limited and firms took advantage of available foreign technologies. As the technological sophistication of production processes matured and the depth and complexity of knowledge for effective absorption grew, firms increasingly resorted to formal means of ITT and governments strengthened the IPR regime.

In a nutshell, the evidence suggests that the nature of ITT and appropriate policies follow a technology ladder. Many middle-income developing countries are at the duplicative imitation stage, hoping to absorb free or cheap foreign technologies into labor-intensive export production and evolve higher value-added strategies over time. The poorest countries have barely stepped onto this stage of the ladder. This suggests a differentiated approach is needed for policy and multilateral rulemaking. Specifically, the policy priority - both national and foreign — in poor countries with weak institutions and limited R\&D capacity is to improve the business environment, with liberal trade policies to encourage imports of technology embodied in goods. Such countries should be exempt from strong IPR obligations and have access to mechanisms to reduce the cost of imports of IPR-protected goods. This could be achieved through either a direct subsidy or a differential pricing scheme. The latter would be in the interest of technology owners if there are complementary actions taken by source country governments to prevent arbitrage (re-exports), because of differences in demand conditions in source and host (importing) countries).

Given that absorptive capacity is weak in low-income countries, the emphasis should be on using trade to benefit from foreign knowledge and acquiring technology through FDI. ${ }^{21}$ Licensing is not a realistic option for LDCs given weak business environments and absorptive capacity. In poor countries the need for (payoff to) FDI is

\footnotetext{
${ }^{20}$ See Kim (2002) and Maskus (2000).

${ }^{21}$ This also has implications for domestic competition and regulatory policies, and the role of the state in the production and trade of inputs. For example, many governments in developing countries have had direct public involvement in (regulation of) the production, trade and use of seed and other agricultural inputs. Efforts to expose these sectors to competition have been found to improve access to inputs, including technology. Countries that pursued regulatory reforms saw farmers introduce more new technology and expand production, trade, and use of inputs, with increased use of private technology resulting in higher yields and incomes (Gisselquist, Nash and Pray 2002).
} 
greater as the incentives for (and ability to benefit from) licensing or joint ventures are lower. Indeed, this situation may provide a case for outward FDI investment incentives by high-income countries as part of their development assistance - an example is the provision of investment guarantees. These could directly address poor countries' weak investment climates, while not distorting the sectoral allocation of FDI as long as they are horizontal in nature. As discussed below, rich countries can also do more to encourage temporary movement of people, both for educational purposes and to provide access to work experience on a temporary basis.

As countries move up the income and technology ladder, they will gain more from IPRs. These are necessary for licensing and will benefit home entrepreneurs and innovators. There may still be a case for subsidizing the cost of acquiring foreign knowledge through licensing. Based on the experience of Asian economies, developing countries should adopt standards for patentability, novelty, and utility that are stricter (i.e., they raise a higher bar to patenting) than those found in the US and EU members. This is currently not constrained by TRIPS, which does not specify any of the substantive criteria on the basis of which IPRs are awarded. Upper-middle-income countries should adopt the full TRIPs package and would benefit less from subsidy schemes to lower the price of technology.

\section{Source-Country Policies}

Perhaps the most powerful indirect incentive for ITT that source countries could provide is to grant significant market access for products in which poor countries have a comparative advantage. The linkage between ITT and market access is to recognize the role that market size and growth play in attracting trade and FDI, and the associated incentives to invest in new technologies if export markets were more assured.

TRIPS Article 66.2 imposes an obligation on developed economies to find means of increasing ITT to the LDCs. This requirement should be extended to other developing countries on a graduated basis. One option would be for governments in developed countries to increase technical and financial assistance for improving the ability of poor countries to absorb technology and engage in trade. Among key issues here would be 
capacity building in IPRs and technical regulations and standards, establishing public and public-private research facilities, and facilitating trade in technology-related services.

Investment guarantees, fiscal incentives or other subsidies for ITT should also be considered. It would be difficult for OECD governments to envision fiscal incentives for transferring technology without offering similar incentives to firms to locate in or provide technologies to lower-income areas in their own countries. However, such discrimination typically works the other way, in that no incentives are offered to firms to locate in developing countries. Indeed, local and state governments often offer large tax incentives to induce firms to establish facilities or to remain. One option is for central governments to offer identical fiscal benefits to firms transferring technologies to developing countries as are available for transfers to disadvantaged home regions. Developed countries could also offer the same tax advantages for R\&D performed abroad as for R\&D done at home.

In designing such incentives for their firms, home countries should tailor interventions towards those channels that are most appropriate for countries at different stages of development. Given the forgoing arguments in favor of FDI over licensing in low-income countries, for example, policies that aim to subsidize direct transfers of technology through licensing may not be very beneficial to poor countries, no matter how well intentioned. A better approach would be to ensure that incentives target (or minimally do not discriminate against) outward FDI. Home countries should also differentiate between countries in actions to lower the consumption cost of technologyintensive imports. This can be done through the promotion of differential pricing schemes, targeting especially the poorest nations. While not a direct ITT policy, such price segmentation would avoid undesirable reverse transfers from South to North through arbitrage.

Other options to increase incentives for outward flows of ITT include:

- Tax deductions for contributions of technology to non-profit entities engaged in ITT, taking the form of grants, technical assistance, or mature patent rights.

- Fiscal incentives to encourage enterprises to employ, on a temporary basis, recent science, engineering and management graduates from developing countries. Here there are potential synergies with efforts to expand the temporary movement of natural service suppliers under mode 4 of the GATS. 
- Public resources, such as those from the National Science Foundation in the United States, could be used to support research into the technology needs of developing countries, including areas that would be of greatest productivity in poor countries for social needs, such as water treatment, energy, and the environment. Technologies developed under such programs could be made publicly available if transferred through public resources.

- Universities could be encouraged to recruit and train students from LDCs in science, technology, and management. Financial incentives that tap into development aid funding for setting up degree programs through distance learning or even foreign establishments may be particularly effective in this context.

- In addition to such incentive schemes, attention could also center on increasing information flows. For example, in recognition of the role that technical standards play in diffusing production and certification technologies, developed countries could finance participation by experts from developing countries in their standards bodies.

- Finally, developed countries could purchase patents on key technologies for free use in developing countries (Maskus 2003). This would maintain the incentive to invest in $R \& D$ while lowering the cost of acquisition for poor countries.

\section{Multilateral Cooperation: Options and Implications}

Many of the above suggestions will come at a cost to source countries, weakening the incentives to implement them. This provides a potential rationale for embedding commitments on the part of high-income countries into the WTO or other trade agreements. Other proposed actions may require safeguarding the ability of countries to pursue them, and therefore a revisiting of existing rules or development of new rules. It is incontrovertible that certain avenues that were used in the past to pursue industrialization have been narrowed as a result of the WTO regime - an example is TRIMS. The foregoing suggests there is a need for "policy space" to encourage ITT. In general, WTO rules do not constrain the types of policies discussed above, while greater action by source countries to increase ITT is mostly part of the development aid agenda. However, more can and should be done in the WTO. 
As emphasized by Helleiner (2000), Finger (2002), and Sabel and Reddy (2002), among others, given significant differences in circumstances, countries need the freedom to experiment with domestic regulatory policies. This suggests that detailed international harmonization of industrial policy interventions is inappropriate. However, as argued below, multilateral monitoring and information exchange mechanisms can play a useful role in preventing capture and helping to learn what constitutes effective policies. There is a close connection between ITT discussions in the WTO and the concept of special and differential treatment (SDT) of developing countries. The argument developed above that needs (market failures) differ depending on the type of country suggests that ITT policies should be differentiated. The same is arguably true of SDT more generally, although this is resisted by many developing countries. ${ }^{22}$ What follows discusses a number of key areas where actions could be considered in the WTO to encourage ITT.

\section{Subsidies}

The WTO Agreement on Subsidies and Countervailing Measures (ASCM) divides subsidies into three categories: (i) prohibited; (ii) actionable; and (iii) non-actionable. $R \& D$ and related technology subsidies are non-actionable if they are not specific, or, if specific, satisfy certain conditions laid out in Art. 8:2(a-c) ASCM. This article covers "assistance for research activities conducted by firms or by higher education or research establishments on a contract basis with firms." Fundamental research, defined as "an enlargement of general scientific and technical knowledge not linked to industrial or commercial objectives" is not covered. ${ }^{23}$ By incorporating the principle of R\&D subsidy freedom, the ASCM implicitly accepts locational competition between governments.

The provisions on non-actionability of R\&D subsidies lapsed in 1999. Arguably this should be reversed to ensure that developing countries are able to pursue these types of policies. In defining what is permitted, scope should exist to adopt measures that can be justified on the basis of externalities of the type identified by Hausmann and Rodrik (2002), discussed above. This does not necessarily mean complete freedom or policy space - arguably there is an important role for multilateral disciplines to help

\footnotetext{
${ }^{22}$ See Hoekman, Michalopoulos and Winters (2003) for a more extensive discussion of the need for and options to move towards greater differentiation in SDT in the WTO.

${ }^{23}$ A distinction is made between industrial research and pre-competitive development activity. For the former the maximum amount of government participation is $75 \%$; for the latter the maximum is $50 \%$.
} 
governments control subsidy policies and enhance the credibility of exit mechanisms (graduation) and to prevent capture. One approach would be to adopt monitoring and surveillance mechanisms in the WTO that are aimed at increasing information on the effect and effectiveness of policies that aim at encouraging innovation.

\section{Temporary Movement of People and Labor Turnover}

Learning by doing and subsequent labor turnover is an important channel of ITT. While most of the attention in the (limited) literature has focused on labor turnover associated with FDI, international movement of people has a potentially much larger role to play in fostering ITT. In order to be most beneficial to developing countries, policies should encourage temporary movement of people. The classic problem with movement of people across borders is that this is often long-term and can give rise to a brain drain, in the process being potentially negative for home country welfare. Such problems do not arise if the movement is temporary, and returnees apply new skills and knowledge in the domestic economy. Temporary movement is not a panacea — returnees need to be able to apply their skills, which in turn depends importantly on the investment climate. However, expanding the pool of people that have foreign professional experience could generate pressure to implement needed improvements.

Negotiations over the temporary cross-border movement of people have already been launched in the WTO. This is part of the services talks, as one mode of supplying services is through the temporary movement of a service supplier (mode 4 of the GATS). Although the focus of the GATS is limited to people providing services, the GATS approach could be extended to apply to a category of personnel that relocate temporarily in order to increase their human capital and acquire new skills. In effect, rather than regarding such temporary movements as a developing-country export activity as is currently the case under GATS, movements could also be regarded as a mechanism for host countries to export knowledge to developing countries. While it may not be feasible or appropriate to incorporate this into the GATS, the mode 4 precedent might be used to negotiate a stand-alone arrangement under which developing countries are granted additional temporary visa allocations for working in OECD countries that is motivated by ITT objectives. This would also be an obvious way to provide concrete SDT to 
developing countries. ${ }^{24}$ The mechanics of how such a visa allocation mechanism might work could be similar to the GATS visa regime that has been suggested by a number of WTO members (Mattoo and Carzaniga 2003).

Donor countries and organizations could also consider establishing special trust funds for the training of scientific and technical personnel, for facilitating the transfer of technologies that are particularly sensitive for the provision of public goods, and for encouraging research in developing countries (Roffe 2002). To the extent that data and research results are made available at some cost, differential pricing schemes for governments and institutions in poor countries could be encouraged. Efforts to encourage research participation by scientists and engineers from developing countries could be written into grant proposals. Marginal visa allocations could be aimed at students and researchers from poor countries. More generally, developed countries could commit themselves to help developing nations build capacity for improving educational and scientific processes, including their ability to benefit from available international information and the Internet.

\section{IPRs and TRIPS}

Various possibilities might be pursued at the multilateral level, and space constraints prevent a comprehensive discussion (see Maskus 2003). First, the terms of TRIPS Article 66.2 could be expanded from least developed countries to include all developing countries without a significant domestic science and technology base. Second, a special fee (tax) on patent applications could be considered (e.g., through the Patent Cooperation Treaty), with revenues earmarked for improving IPR administrative systems in developing countries. Poor countries have little incentive to fund IPR enforcement as the primary beneficiaries are OECD firms. Third, given different interests of developing countries regarding criteria for patentability, novelty, and utility, efforts toward harmonization of criteria or tests should initially be limited to the regional level, through, for example, regional examination offices that apply regional standards.

\footnotetext{
${ }^{24}$ A proposal by the LDC Group in the WTO that they be given preferential access to a mode 4 'quota' as part of the GATS negotiations goes in this direction.
} 


\section{Competition policy}

Poor countries face major difficulties in developing the appropriate expertise for developing and enforcing anti-monopoly laws. One way for governments in developing countries to feel more confident about the system would be for authorities in the developed countries to undertake enforcement actions against firms headquartered or located in their jurisdictions. A committed effort on the part of developed countries to prevent market-power abuses on developing country markets by their sellers of technology can do much to achieve the goals of TRIPS Article $66 .{ }^{25}$

\section{Information Exchange and Multilateral Monitoring}

To reduce problems of asymmetric information, international cooperation could seek to create a conduit for knowledge about successful technology-acquisition programs that have been undertaken by national and sub-national governments in the past. ${ }^{26}$ Many developing countries have little knowledge about the structure of international ITT contracts: What are reasonable royalty rates? What sort of conditions have sellers of technology been willing to accept? What types of contract clauses have proved helpful in encouraging local technological development? Answers to such important questions are available but their dissemination requires concerted efforts on the part of the private as well as the public sector of developed countries. Privacy concerns might be raised as an issue but these cannot be a major obstacle: past licensing contracts that have already expired can hardly raise serious privacy concerns. Countries that underwent rapid technological development can teach developing countries important lessons if they are willing and able to tap the knowledge available in both public and private sectors. Sharing of country experiences that does not utilize the information available from the private sector can only be of limited use.

As mentioned, more emphasis on information exchange and mutual (multilateral) monitoring would also be beneficial. This should focus on the effects of applied policies in achieving objectives. Rather than regulate what countries may or may not do to encourage ITT and innovation through substantive policy harmonization, the aim would

\footnotetext{
${ }^{25}$ Inventors might also transfer technologies under terms that monopolize output markets rather than extracting rents on the transfer itself. This would provide an additional rationale for antitrust action.

${ }^{26}$ Thus, it is well documented that the Japanese Ministry of Industry and Trade (MITI) played an active role in encouraging ITT. However, practical details about the policies adopted are not readily available.
} 
be to establish a broad framework that requires countries to engage in a regular exchange of information and to consider assessments of their policies in attaining their stated objectives. Sabel and Reddy (2002) provide a conceptual sketch of such a general "learning to learn" framework that could be applied to the ITT arena. What organization should take up this task is an important question. The WTO is a candidate, but it is unclear whether it has a comparative advantage in fostering this type of voluntary cooperation. Another possibility is to use UNCTAD or UNIDO as a venue, or to emulate the approach that has been taken in the competition policy arena with the creation of the Global Competition Forum, a network of competition agencies and regulators.

\section{Protecting and Expanding the Global Commons for Knowledge}

Another proposal that has considerable potential to expand ITT to poor countries is to negotiate a WTO Agreement on Access to Basic Science and Technology (ABST) (Barton and Maskus 2004). This would place into the public domain the results of publicly funded research. The idea is to preserve and enhance the global commons in science and technology without unduly restricting private rights in commercial technologies. The agreement could cover either input liberalization—under which researchers from other countries could participate in, or compete with, local research teams for grants and subsidies, possibly combined with increased opportunities for temporary migration of scientific personnel and additional student visas; output liberalization - under which researchers in other countries would have access to nationally generated science and data, including scientific databases, thus ensuring that IPRs not limit access to basic scientific knowledge; or, full liberalization. The latter would combine the first two, both expanding international flows of research contracts and personnel and increasing global access to outcomes. In practice, it may be necessary to adopt something like a GATS approach to the ABST, permitting governments to reserve sensitive areas of technology and to designate different levels of commitment to open access. Safeguards for security-related regulation would be required as well.

\section{Concluding Remarks}

ITT flows depend on many factors, including proximity to markets, size, growth, competition conditions, human capital, governance, and infrastructure. Many of these 
variables are affected by policy. Determining the optimal policy to maximize ITT is difficult. Despite an abundance of research on the channels of ITT, there is still much uncertainty regarding the extent of market failures and potential spillovers associated with alternative channels of ITT, greatly complicating the identification of good policies. That said, the analysis identified some rules of thumb for policy intervention aimed at improving development outcomes, as well as a number of specific proposals.

We summarize the main policy implications of our analysis in Table 4, distinguishing between low-income, lower-middle-income and upper-middle-income countries. These categories are for illustrative purposes only. They are useful primarily in distinguishing between the types of general policies that are most appropriate for countries at different levels of development. We have argued that countries pursuing relatively closed trade policies fail to achieve the benefits from technology implicit in international trade. Given the considerable evidence that R\&D-intensive capital goods imports from high-income countries is associated with higher TFP in developing economies, we argue for liberal trade policies for all types of countries. Spillovers from technology-intensive imports exist at the aggregate, intra-industry, and inter-industry levels. Exports to developed countries also are associated with higher domestic productivity, as firms must use technologies that satisfy international quality standards.

The literature on spillovers in developing countries from FDI is more mixed, with evidence of vertical spillovers being the most compelling (Saggi 2002). FDI is likely to be particularly important for LDCs. The weak investment climates that prevail in many of these countries may justify a temporary case for encouragement of FDI inflows to these countries, although such incentives should avoid discrimination across sectors. We argue also for improving the infrastructure and reducing entry barriers for local firms that could be effective input suppliers for vertical MNEs.

While licensing is an important source of technical transformation, successful transfer generally requires capacity to learn and adaptive investments by local firms to apply technologies. Poor countries are most likely to achieve these gains by taking advantage of mature technologies that are in the public domain or available cheaply. Thus, policy could aim at improving information flows for domestic enterprises about such technologies. A secondary priority in low-income nations could be programs to 
build skills and R\&D capacity. Middle-income countries in which firms have engineering skills and active R\&D programs are more likely to be the recipients of (and benefit from) significant licensing flows. However, moving up the technology ladder requires expanding inward flows of voluntary licensing and encouraging local R\&D and adaptation. To do this, policy efforts could focus on reducing the costs of absorbing technology and enhancing the direct flow of ITT. The upper-middle-income economies presumably require no active intervention in licensing, where technology markets may be expected to operate effectively. Note that our analysis in no case supports extensive government involvement in selecting technologies or placing restrictions on the use of technical information.

For local economies to gain productivity from ITT, broader policy initiatives are important. This is a complex task that involves building human capital, expanding national innovation systems, and effectively protecting IPRs, which may be critical for fostering innovation and supporting trade in knowledge. Economic reasoning and history strongly indicate that IPR regimes should vary depending on levels of development and technological capacities. In Table 4 we hint at this issue, though far more detail could be added. ${ }^{27}$ Thus, low-income countries would find it advantageous to enforce basic protection of trademarks, trade secrets, utility models, and industrial designs in order to encourage both local small-scale innovation and inward FDI in labor-intensive technologies. However, it is inadvisable to move beyond minimum TRIPS standards, while requirements for patents, plant variety rights, and copyrights should be as procompetitive as possible. The LDCs may be expected to do relatively little in terms of enforcing foreign patent rights in any case unless there are dedicated funding mechanisms found for this purpose. There is a strong case for forbearance by OECD governments in pursuing TRIPS-related dispute settlement at the WTO. For their part, lower-middleincome countries should take advantage of TRIPS flexibilities while offering somewhat wider scope of protection of IPRs.

We also list suggested host-country policies for temporary movement of persons and general technology policies. Lower-middle-income economies could gain from investing in R\&D support, especially as regards collaborations between public research

\footnotetext{
${ }^{27}$ World Bank (2001) offers extensive discussion.
} 
entities and private enterprises, as part of their innovation systems. Developing economies at all levels have an interest in temporary movement of technical workers abroad for education and training, while upper-middle-income countries could see growing two-way movements in skilled personnel.

The bottom half of Table 4 encapsulates policy recommendations for source economies in the OECD looking to encourage ITT to poor countries. Fiscal incentives may be an effective means for overcoming market failures in ITT. As regards FDI, such incentives could be largest for the low-income countries and in any case at least equal to those offered for activity in OECD countries. OECD governments could improve flows of public-domain technologies with appropriate subsidies, while there is scope for assisting the establishment of joint ventures. We also argue for establishment of extensive price differentiation for exports of IPR products.

Many of the suggestions made in this paper can be implemented unilaterally. However, some require action in the WTO, and many can be made more credible by incorporating them into the WTO as specific commitments. One way this could be done is as part of a new approach to SDT, as suggested by Hoekman, Michalopoulos and Winters (2004). Alternatively the various ITT-related policy initiatives could be embedded in a mix of existing WTO agreements (e.g., the ASCM, TRIPS) and new ones (e.g., the ABST suggestion). Whatever path is chosen, effectiveness requires clear criteria be used to differentiate between beneficiary countries. We have not been very explicit about what such criteria might be beyond the broad income-based categories used above. This is an issue that will have to be decided by WTO members. Our preference is for broad, transparent categories to minimize transactions costs and uncertainty.

Another issue is whether the pro-active ITT measures we have suggested for source countries to undertake should take the form of binding and enforceable commitments under the WTO. In our view this would be inappropriate. A "soft law" approach that establishes broad guidelines and relies on ensuring transparency and accountability via regular multilateral monitoring of performance is likely to be a more effective mechanism to increase cooperation and compliance with commitments. The same is true with regard to allowing developing countries to pursue general technologyrelated policies and to encourage the use of specific channels of ITT. However, in other 
cases, such as the suggested implicit exemption on enforcement of TRIPS for lowincome countries, a change in the relevant WTO rules is needed. More generally, a good case exists that WTO disciplines on trade liberalization and tariff binding should apply to developing countries (Hoekman, Michalopoulos and Winters 2004). 
Table 4: A 'Rule-of-Thumb’ Typology and Examples of ITT Policies

\begin{tabular}{|c|c|c|c|c|c|c|}
\hline & Trade in goods & FDI & $\begin{array}{c}\text { Trade in } \\
\text { knowledge } \\
\text { (licensing) }\end{array}$ & IPRs & $\begin{array}{l}\text { Temporary } \\
\text { movement }\end{array}$ & $\begin{array}{c}\text { General technology } \\
\text { policies }\end{array}$ \\
\hline \multicolumn{7}{|l|}{$\begin{array}{l}\text { Own policies } \\
\text { in: }\end{array}$} \\
\hline $\begin{array}{l}\text { Low-income } \\
\text { countries }\end{array}$ & Liberal access & $\begin{array}{l}\text { Inward investment } \\
\text { promotion }\end{array}$ & $\begin{array}{l}\text { Improve information } \\
\text { flows about public } \\
\text { domain and mature } \\
\text { technologies }\end{array}$ & $\begin{array}{l}\text { Basic protection and } \\
\text { minimum standards }\end{array}$ & $\begin{array}{l}\text { Incentives for } \\
\text { education abroad }\end{array}$ & $\begin{array}{l}\text { Basic education; improve } \\
\text { infrastructure; reduce entry } \\
\text { barriers }\end{array}$ \\
\hline $\begin{array}{l}\text { Lower middle } \\
\text { Income } \\
\text { countries }\end{array}$ & Liberal access & $\begin{array}{l}\text { Inward investment } \\
\text { promotion }\end{array}$ & $\begin{array}{l}\text { Improve information; } \\
\text { limited incentives for } \\
\text { licensing }\end{array}$ & $\begin{array}{l}\text { Wider scope of } \\
\text { protection; employ } \\
\text { flexibilities }\end{array}$ & $\begin{array}{l}\text { Incentives for } \\
\text { education abroad and } \\
\text { training-related } \\
\text { movement }\end{array}$ & $\begin{array}{l}\text { R\&D support policies; improve } \\
\text { public-private collaboration }\end{array}$ \\
\hline $\begin{array}{l}\text { Upper middle } \\
\text { income } \\
\text { countries }\end{array}$ & Liberal access & No active policy & No active policy & Full TRIPS & $\begin{array}{l}\text { Encourage two-way } \\
\text { mobility }\end{array}$ & R\&D support policies \\
\hline \multicolumn{7}{|l|}{$\begin{array}{l}\text { OECD } \\
\text { policies } \\
\text { towards: } \\
\end{array}$} \\
\hline $\begin{array}{l}\text { Low-income } \\
\text { countries }\end{array}$ & $\begin{array}{l}\text { Subsidize 'public } \\
\text { good' type imports }\end{array}$ & $\begin{array}{l}\text { Incentives for } \\
\text { outward flows } \\
\text { exceeding those for } \\
\text { FDI to LMICs (see } \\
\text { below) }\end{array}$ & $\begin{array}{l}\text { Subsidize transfer of } \\
\text { public domain and } \\
\text { mature technologies }\end{array}$ & $\begin{array}{l}\text { Forbearance in } \\
\text { disputes; differential } \\
\text { pricing for exports of } \\
\text { IPR products; } \\
\text { assistance in } \\
\text { competition policy }\end{array}$ & $\begin{array}{l}\text { Preferential access; } \\
\text { subsidies for } \\
\text { education and } \\
\text { temporary } \\
\text { employment }\end{array}$ & $\begin{array}{l}\text { Support for public and public- } \\
\text { private research facilities; } \\
\text { incentives for universities to } \\
\text { accept DC students in STI } \\
\text { disciplines }\end{array}$ \\
\hline $\begin{array}{l}\text { Lower middle } \\
\text { income } \\
\text { countries }\end{array}$ & No controls & $\begin{array}{l}\text { Incentives that equal } \\
\text { those granted for } \\
\text { domestic } \\
\text { disadvantaged } \\
\text { regions }\end{array}$ & $\begin{array}{l}\text { Assistance in } \\
\text { establishment of joint } \\
\text { venture partnerships; } \\
\text { matching grants }\end{array}$ & $\begin{array}{l}\text { Differential pricing } \\
\text { of public good type } \\
\text { IPR protected goods; } \\
\text { assistance in } \\
\text { competition policy }\end{array}$ & $\begin{array}{l}\text { Wider access for } \\
\text { education and } \\
\text { training and } \\
\text { temporary } \\
\text { employment } \\
\end{array}$ & $\begin{array}{l}\text { Fiscal incentives for R\&D } \\
\text { performed in developing } \\
\text { countries (DCs) and temporary } \\
\text { employment of DC scientific } \\
\text { personnel and engineers. }\end{array}$ \\
\hline $\begin{array}{l}\text { Upper middle } \\
\text { income } \\
\text { countries }\end{array}$ & No controls & No incentives & No active policy & No active policy & $\begin{array}{l}\text { Encourage mode } 4 \\
\text { type mobility }\end{array}$ & No active policy \\
\hline
\end{tabular}




\section{References}

Aitken, B.J. and A.E. Harrison (1999). "Do domestic firms benefit from direct foreign investment? Evidence from Venezuela", American Economic Review, 89, 605-618.

Amsden, A. (1989), Asia's Next Giant: South Korea and Late Industrialization, Oxford University Press.

Arora, Ashish, Andrea Fosfuri, and Alfonso Gambardella (2001), Markets for Technology: The Economics of Innovation and Corporate Strategy (Cambridge; MIT Press).

Audretsch, David and Maryann Feldman (1994) "Knowledge Spillovers and the Geography of Innovation and Production," CEPR Discussion Paper 953.

Barton, John and Keith E. Maskus (2004), "Economic Perspectives on a Multilateral Agreement on Open Access to Basic Science and Technology," University of Colorado, manuscript.

Blomstrom, Magnus and Ari Kokko (1997), "How Foreign Investment Affects Host Countries," World Bank PRD Working Paper No. 1745.

Blyde, Juan S. and Cristina Acea (2002), "The Effects of Intellectual Property Rights on Trade and FDI in Latin America," Inter-American Development Bank, manuscript.

Coe, David T., and Elhanan Helpman (1995), "International R\&D Spillovers," European Economic Review 39: 859-87.

Coe, David T., Elhanan Helpman, and Alexander W. Hoffmaister (1997), "North-South R\&D Spillovers," The Economic Journal 107: 13-149.

Correa, Carlos M. (2003), "Can the TRIPS Agreement Foster Technology Transfer to Developing Countries?" Duke University, manuscript.

Eaton, Jonathan and Samuel Kortum (1996), "Trade in Ideas: Patenting and Productivity in the OECD," Journal of International Economics 40: 251-278.

Eaton, Jonathan and Samuel Kortum (1999), "International Technology Diffusion: Theory and Measurement" International Economic Review, 40(3), 537-570.

Evenson, R.E. (2004), "Agricultural Research and Intellectual Property Rights," in K.E. Maskus and J.H. Reichman, eds., International Public Goods and Transfer of Technology under a Globalized Intellectual Property Regime (Cambridge: Cambridge University Press), forthcoming.

Evenson, R.E. and L. Westphal (1995), "Technological Change and Technology Strategy," in H. Chenery and T.N. Srinivasan, Eds. Handbook of Development Economics: Vol. 3 (Amsterdam: North-Holland).

Finger, J. M. (2002), "The Doha Agenda and Development" Manila: Asian Development Bank.

Gisselquist, David, John Nash and Carl Pray. 2002. "Deregulating the Transfer of Agricultural Technology: Lessons from Bangladesh, India, Turkey, and Zimbabwe," World Bank Research Observer, 17: 237-65.

Grossman, G. and E. Helpman (1991), Innovation and Growth in the World Economy. MIT Press.

Hausmann, R. and D. Rodrik (2002), "Economic Development as Self-Discovery," mimeo.

Helleiner, G. (2000), "Markets, Politics, and Globalization: Can the Global Economy be Civilized?," $10^{\text {th }}$ Prebisch lecture, UNCTAD, mimeo (www.unctad.org).

Hoekman, B. C. Michalopoulos and L. Alan Winters (2004), "Special and Differential Treatment in the WTO After Cancun," The World Economy (forthcoming).

Keller, Wolfgang (1996), "Absorptive Capacity: On the Creation and Acquisition of Technology in Development," Journal of Development Economics , 49:199-227.

Keller, Wolfgang (2002), 'Geographic Localization of International Technology Diffusion,' American Economic Review 92: 120-142.

Kim, Linsu (2002), 'Technology Transfer and Intellectual Property rights: Lessons from Korea's Experience,' UNCTAD/ICTSD Issue paper No.2.(www.iprsonline.org).

Kokko, Ari, Ruben Tansini, and Mario Zejan (1997). "Trade Regimes and Spillover Effects of FDI: Evidence From Uruguay," Stockholm School of Economics, mimeo. 
Mansfield, Edwin and Anthony Romeo (1980), "Technology Transfer to Overseas Subsidiaries by U.S. Based Firms," Quarterly Journal of Economics 95: 737-49.

Maskus, Keith E. (2000), Intellectual Property Rights in the Global Economy (Washington DC: Institute for International Economics).

Maskus, Keith E. (2003), "Encouraging International Technology Transfer," ICTSD/UNCTAD Issue Paper No.7. (www.iprsonline.org)

Maskus, Keith E. and Christine McDaniel (1999), "Impacts of the Japanese Patent System on Productivity Growth," Japan and the World Economy 11: 557-574.

Maskus, Keith E. and John S. Wilson, Editors (2001), Quantifying the Impact of Technical Barriers to Trade: Can It Be Done? (Ann Arbor: University of Michigan Press).

Mattoo, Aaditya and Antonia Carzaniga. Editors (2003), Moving People to Deliver Services. Washington DC: World Bank.

McCalman, Phillip (2001), 'Reaping What You Sow: An Empirical Analysis of International Patent Harmonization,' Journal of International Economics 55: 161-186.

Krishna, Pravin and Devashish Mitra (1998), "Trade Liberalization, Market Discipline, and Productivity Growth: India," Journal of Development Economics 56:447-62.

Moran, Theodore (1998), Foreign Direct Investment and Development, Washington D.C.: Institute for International Economics.

Nicholson, Michael (2002), "Intellectual Property Rights and International Technology Transfer: The Impact of Industry Characteristics," U.S. Federal Trade Commission, manuscript.

Noland, Marcus and Howard Pack (2003), Industrial Policy in an Era of Globalization: Lessons from Asia. Washington DC: Institute of International Economics.

Parente, Stephen L. and Edward C. Prescott (1994), "Barriers to Technology Adoption and Development," Journal of Political Economy 102: 298-321.

Patel, S., P. Roffe and A. Yusuf (2000), International Technology Transfer: The Origins and Aftermath of the UN Negotiations on a Draft Code of Conduct (The Hague: Kluwer).

Peri, Giovanni (2003), 'Knowledge Flows, R\&D Spillovers, and Innovation', University of California at Davis, manuscript.

Rhee, Yung Whee (1990), "The Catalyst Model of Development: Lessons from Bangladesh's Success with Garment Exports," World Development 18: 333-346.

Rodrik, Dani. 1993. "Taking Trade Policy Seriously: Export Subsidization as a Case Study in Policy Effectiveness," NBER Working Paper 4567.

Roffe, Pedro (2002), "Preliminary Note on the WTO Working Group on Trade and Transfer of Technology," UNCTAD, manuscript, February.

Sabel, Charles and Sanjay Reddy (2002), "Learning to Learn: Undoing the Gordian Knot of Development Today," Columbia University, mimeo (www.sopde.org/discussion.htm).

Saggi, Kamal (1996), "Entry into a Foreign Market: Foreign Direct Investment versus Licensing," Review of International Economics 4: 99-104.

Saggi, Kamal (2002), "Trade, Foreign Direct Investment, and International Technology Transfer: A Survey," World Bank Research Observer 17, 191-235.

Saggi, Kamal (2003), "Encouraging Technology Transfer to Developing Countries: Role of the WTO," report for Commonwealth Secretariat.

Sell, Susan K. (1998), Power and Ideas: North-South Politics of Intellectual Property and Antitrust (Albany: State University of New York Press).

Schiff, M. and Y. Wang (2002), "On the Quantity and Quality of Knowledge: The Impact of Openness and Foreign R\&D on R\&D Spillovers," World Bank, mimeo.

Schiff, Maurice, Yanling Wang and Marcelo Olarreaga (2002), "North-South and South-South Trade-Related Technology Diffusion: An Industry Level Analysis," World Bank, mimeo.

Smarzynska, Beata K. (2003), 'Spillovers from Foreign Direct Investment through Backward and Forward Linkages: The Case of Lithuania,' American Economic Review, forthcoming 
Smarzynska, Beata K. (2004). "Composition of Foreign Direct Investment and Protection of Intellectual Property Rights in Transition Economies," European Economic Review, 48(1).

Smith, Pamela J. (2001), "How Do Foreign Patent Rights Affect U.S. Exports, Affiliate Sales, and Licenses?" Journal of International Economics 55: 411-440.

Tybout, James (2000), "Manufacturing Firms in Developing Countries: How Well Do They Do and Why?," Journal of Economic Literature 38:11-44.

UNCTAD (2002), World Investment Report 2002 (Geneva: UNCTAD).

World Bank (2001), Global Economic Prospects and the Developing Countries 2002: Making Trade Work for the World's Poor (Washington DC: The World Bank).

Yang, Guifang and Keith E. Maskus (2001), "Intellectual Property Rights and Licensing: An Econometric Investigation," Weltwirtschaftliches Archiv 137: 58-79. 